\title{
MEMBANGUN INTEGRITAS DI SATUAN PENDIDIKAN STRATEGI \\ KEPEMIMPINAN KEPALA SEKOLAH, GURU, ORANG TUA, DAN \\ MASYARAKAT DALAM MEMBENTUK KARAKTER SISWA \\ ( Studi Kasus Di SDN Antara Kecamatan Trienggadeng Kabupaten Pidie Jaya)
}

\section{Marsalin}

\begin{abstract}
ABSTRAK
Penelitian ini bertujuan untuk menderskripsikan strategi kepala sekolah, guru, orang tua, dan masyarakat dalam pembentukan karakter siswa di sekolah dasar. Pendekatan penelitian yang diguna- kan adalah kualitatif dengan jenis studi kasus. Instrumen penelitian adalah peneliti sendiri. Pengum- pulan data menggunakan wawancara mendalam, observasi partisipasi dan dokumentasi. Responden penelitian bersifat snow-ball. Teknik analisis data menggunakan model Creswell (2014). Keabsahan data digunakan kriteria kredibilitas, transferabilitas, dependabilitas, dan komfirmabilitas. Kesimpulan penelitian adalah strategi kepala sekolah dalam membentuk karakter siswa dengan filosofis kepemim- pinan, keteladanan, kedisiplinan, kepemimpinan instruksional, kepemimpinan mutu, serta pemberda- yaan guru dan tenaga kependidikan. Strategi guru adalah keteladanan, pembiasaan, dan sentuhan kalbu. Strategi orang tua dan masyarakat adalah komunikasi efektif dan kemitraan efektif.
\end{abstract}

Kata Kunci: Strategi, Kepala Sekolah, Guru, Masyarakat, Karakter

\section{THE LEADERSHIP STRATEGIES OF SCHOOL PRINCIPALS, TEACHERS, PARENTS, AND THE COMMUNITIES IN BUILDING THE STUDENTS' CHARACTER}

\begin{abstract}
This study was aimed to analyze the strategies of the school principals, teachers, parents, and communitiesinbuilding the student character in elementary schools. This study used the qualitative approach using the case study type. The research instrumentswere researhers themselves. The data were collected using the in-depth interview, participation observation, and documentation. The respon- dents were selected using the snowball sampling technique. The data were analyzed using the model developed by Creswell (2014). The verification of the data was done through credibility, transferabi- lity, dependability, and confirmability criteria. The findings showed that the strategies of the school principals in building the students' character were the philosophy of leadership, modelling, discipline, instructional leadership, quality leadership, and teacher and staff empowerment. The strategies of the teachers were modelling, habituation, and through touching the heart. The strategies of the parents and communities were effective communication and partnership.
\end{abstract}

Keywords: strategy, principalship, teacher, community, character building

\section{Pendahuluan}

Strategi berasal dari bahasa Yunani tegos, yang berarti 'tentara', sedang 'ago' berarti 'memimpin'. Strategi mula-mula digunakan di dunia kemiliteran untuk mendapat kemenangan dalam pertempuran melawan musuh. Istilah perencanaan strategi di bidang manajemen muncul tahun 1950-an dan populer tahun 1960-an sampai tahun 1970-an. Terdapat 66 definisi strategi yang diidentifikasikan oleh Abraham 2004) yang menyimpulkan bahwa strategi adalah pendekatan umum yang bersifat jangka panjang. Sebaliknya, taktik adalah pendekatan khusus yang bersifat jangka pendek. Era global oleh 
Richard Crawford disebut sebagai Era of Human Capital, yaitu suatu era ketika perkembangan ilmu pengetahuan dan teknologi, khususya teknologi telekomunikasi berkembangan sangat pesat. Hal tersebut memberikan sesuatu yang serba mudah (instant) nilai yang dianut oleh generasi muda. Perilaku tersebut terkadang tidak sesuai dengan budaya tata nilai dan sopan santun bahkan tidak sesua dengan norma agama. Hal ini sangat berpenga ruh terhadap kehidupan generasi muda di masa depan. Generasi masa depan harus merupakan generasi yang berkualitas dan berkarakter agar eksistensi bangsa dan negara serta agama dapat dipertahankan.

Sauri (2011) menyatakan faktor fenomena global merupakan faktor yang paling berpengaruh terhadap tata nilai, karakter dan mentalitas suatu bangsa, sedangkan faktor lain adalah faktor internal yaitu arah pembangunan dunia pendidikan, yaitu pembangunan pendidikan yang berbasis budaya, nilai dan norma yang berlaku di masyarakat dan berorientasi pada subyek (human oriented development). Ini berarti diperlukan arah penyelenggaraan pen- didikan yang berbasis pendidikan karakter.

Gardner (2006) mengemukakan lima kemampuan pikir yang diperlukan untuk masa depan (era global) yang disebutnya dengan is- tilah Five Minds For The Future. (1) The disci- plined Mind, yaitu kemampuan ketangkasan/ keterampilan belajar dan mempelajari bidang tertentu sehingga menjadi sesuatu yang melekat pada dirinya. (2) The synthesizing mind, yaitu kemampuan mengumpulkan, memahami serta mensintesakan berbagai informasi yang dibutuhkannya untuk meningkatkan derajat kehidupannya. (3) The creating mind, yaitu kemam- puan menggunakan berbagai informasi yang telah dipahaminya untuk memecahkan permasalahan atau menghasilkan produk yang bermanfaat, bukan hanya bagi dirinya, tetapi juga bagi lingkungan masyarakatnya.

(4) The respectful mind, yaitu kemampuan dan kesediaan sese- orang untuk menghargai cara berpikir dan ber- tindak orang lain yang berbeda dengan dirinya. (5) The ethical mind, yaitu kesediaan seseorang menjunjung tinggi nilai-nilai etika yang universal. dari lima kemampuan tersebut di atas, empat di antaranya yaitu (2), (3), (4), dan (5) merupakan kemampuan yang terkait dengan karakter siswa, Pendapat ini mengindikasikan pentingnya karakter di masa depan. tetapi, sampai saat ini pendidikan karakter masih dihadapkan pada berbagai permasalahan, baik masalah makro maupun masalah mikro di tingkat sekolah. Permasalahan penyelenggara pendi dikan karakter yang secara emperik dapat kita ketahui melalui berbagai media massa seperti koran dan TV. contoh, kekerasan dalam dunia pendidikan oleh guru terhadap siswa dan oleh sesama siswa, dosen terhadap mahasiswa dan antarmahasiswa, tawuran antarpelajar dan antarmahasiswa, penyalahgunaan obat terlarang oleh siswa SD sampai mahasiswa, korupsi dana biaya operasional sekolah oleh kepala sekolah dan pejabat pendidikan. Cepatnya siswa mengambil keputusan dengan jalan pintas bunuh diri karena tidak lulus UN atau masalah pribadi lainnya, bahkan peristiwa terakhir adalah siswa SMA membunuh gurunya. Pelecehan seksual oleh guru kepada siswanya.

Semua permasalahan karakter tersebut mengindikasikan moral siswa, pendidik, dan pejabatpendidikanmasih belum mampu men gimplementasikanparadigma pendidikan $\mathrm{Ki}$ Hajar Dewantara, yaitu ing ngarso song tulodo, ing madyo mangun karso, tut wuri handayani.

Kenyataan di atas mengindikasikan pula bahwa penanaman nilai-nilai moral, norma, dan pembentukan karakter belum menjadi perhatian utama dalam proses pembelajaran di sekolah. Padahal, UndangUndang Nomor 20 Tahun 2003 tentang Sisdiknas, dan PP Nomor 15 Tahun 2005 serta Undang-Undang Nomor 14 Tahun 2005 tentang Guru dan Dosen mengamanatkan kompetensi guru harus mampu melaksanakan pembelajaran yang mendidik (peda- gogik), profesional, berkepribadian, 
dan sosial secara utuh sehingga dapat menjadi teladan bagi siswa dan masyarakat. Pendidikan dalam per- spektif sistem pendidikan nasional pada dasar- nya membentuk manusia seutuhnya, yaitu manusia yang berkarakter sekaligus manusia yang cerdas.

Berkaitan dengan hal tersebut, Jalal (2011) menyatakan bahwa pembangunan karakter, selain merupakan upaya perwujudan amanat Pancasila dan pembukaan UUD 1945, juga dilatarbelakangi oleh realita permasalahan kebangsaan yang berkembang saat ini. Ada enam faktor permasalahan kebangsaan yang menjadi latar belakang pentingnya pendidikan karakter bangsa ini, yaitu: (1) krisis kepemimpinan nasional; (2) maraknya korupsi; (3) konflik para elit; (4) memudarnya rasa kemanusiaan; (5) maraknya kejahatan; (6) banyaknya pengguna narkoba dan sejenisnya; (7) disorientasi dan belum dihayatinya nilai nilai Pancasila; (8) keterbatasan perangkat kebijakan terpadu dalam mewujudkan nilai-nilai Pancasila; (9) bergesernya nilai etika dalam kehidupan berbangsa dan berne- gara; (10) memudarnya kesadaran terhadap ni- lai-nilai budaya bangsa; (11) ancaman disinter- grasi bangsa; dan (12) melemahnya kemandiri- an bangsa

Arsyad (2010) menyatakan bahwa pendi- dikan karakter adalah kompetensi yang berkaitan dengan hal-hal praktis yang dapat digunakan dalam hidup siswa untuk menghadapi situasi, kondisi dan lokasi yang berbeda-beda. Kompe- tensi yang dimaksud seperti berikut. (1) Percaya pada Tuhan dengan sadar, keterampilan logika (logical skills) and keterampilan analitik (analytical skills) yang membuat mereka cerdas dan sholeh tidak gampang dipengaruhi oleh orang lain, yang muatannya dapat diambil di antara- nya dari buku-buku "retorika kaum bijak". (2) Keterampilan berkomunikasi, baik lisan maupun tulisan dengan menggunakan retorika bijak sehingga membuat mereka tidak hanya baik dan sholeh, tetapi dapat membuat mereka menjadi penganjur kebaikan dan peradaban. (3) Kete- rampilan yang membuat mereka mampu be- kerja dengan motivasi yang sangat tinggi secara mandiri sehingga mereka dapat berkreasi, berinovasi dan memproduksi karya-karya yang gemilang. Namun, pada hal yang sama mereka juga dapat bekerja dalam satu tim organisasi. Kerja tim tersebut dilakukan untuk membuat tatanan sistem yang teratur yang dapat memengaruhi orang lain berbuat kebajikan dan tidak mudah dipengaruhi oleh orang lain karena ke- cerdasannya memilah dan memilih mana yang baik dan mana yang buruk serta kemampuannya untuk menghargai waktu.

Arsyad (2010) menyatakan bahwa pendidikan karakter juga dapat menjadi kurikulum tersembunyi, seperti manajemew aktu, etika dan integritas, kemampuan berpikir, kemauan belajar, komitmen, keingi nan meraih sukses/motivasi, dorongan energi yang kuat/semangat yang sangat tinggi, komunikasi lisan, kreativitas, kemampuan analisis, dapat mengatasi stress, manajemen diri dan mengambil tanggung jawab, penyelesaian masalah kerjasama, mudah beradaptasi dan bijak, kerja tim, kemampuan menjadi pendengar yang baik.

Lickona (2008) menyatakan bahwa ada tiga komponen karakter yang baik. (1) Moral knowing, mencakup moral awareness, knowing moral values, perspective taking, moral reason- ing, decision making, self-knowledge. (2) Moral feeling yang mencakup: conscience, self esteem, emphaty, loving the good, selfcontrol dan hu- mility. (3) Moral action yaitu competence, will dan habit. Ratna Megawangi seperti dikutip Sauri (2011) telah menyusun karakter mulia yang selayaknya dibelajarkan kepada siswa dengan istilah sembilan pilar, yaitu: (1) cinta Tuhan dan kebenaran; (2) tanggung jawab; kedisiplinan dan kemandirian; (3) amanah; (4) hormat dan santun; (5) kasih sayang; kepeduli- an dan kerjasama; (6) percaya diri, kreatif dan pantang menyerah; (7) keadilan dan kepemim- pinan; (8) baik dan rendah hati; dan (9) toleran- si dan cinta damai. Berdasarkan ketiga pendapat di atas, 
dapat disimpulkan bahwa pendidikan karakter adalah sejumlah sifat mulia yang dapat diajarkan dalam rangka membentuk karakter siswa.

Dalam rangka pembentukan karakter sis- wa, Arsyad (2010) menyatakan perlunya meng- asah inner capacity siswa. Inner capacity ada- lah usaha pengembangan kreativitas, proaktivi- tas, inovasi, dan imajinasi. Pengembangan inner capacity adalah pengembangan kemampuan yang tidak mudah diamati, namun secara nyata menjadi kompetensi efektif dan efisien untuk menyelesaikan suatu tugas tertentu secara tuntas. Jika kompetensi tersebut dapat ditum- buhkembangkan, siswa akan mampu memiliki kekuatan dalam merebut setiap peluang bersaing dalam meningkatkan harkat, martabat dan kesejahteraan hidupnya. Masalah lulusan pen- didikan sekarang umumnya terletak pada ku- rangnya kreativitas dan inovasi dalam menghadapi kenyataan hidup dibandingkan dengan orang kreatif dan inovatif, meskipun tidak ber- pendidikan tinggi. Lulusan sekolah yang berka- rakter hanya dapat diperoleh dari pendidikan yang berkualitas tinggi

Pendidikan yang berkualitas memerlukan ketersediaan layanan guru dan tenaga kependidikan yang profesional. Dengan demikian, akan dihasilkan lulusan masyarakat Indonesia masa depan yang memiliki karakter yang kuat, menghormati keragaman budaya sebagai perekat integrasi bangsa, disertai penguasaan dasar- dasar kecakapan hidup (soft skills) dan landasan penguasaan ilmu dan teknologi (hard skills) yang diperlukan untuk tugasnya sebagai indi- vidu di masyarakat, menjunjung tinggi nilai- nilai etika serta bertanggung jawab atas kese- jahteraan bangsa dan tanah air (Brandsford, 2005; Gardner 2006). Meskipun banyak ahli dalam perspektifnya masing-masing telah merumuskan komponen pembentuk karakter, tetapi setiap sekolah dapat merumuskan dan menentukan prioritas pembentuk karakter di sekolahnya (Kemendiknas, 2011). Oleh sebab itu, dalam rangka implementasi strategi pendidikan karakter di sekolah, perlu diperhatikan beberapa prinsip dasar dalam pendidikan karakter yang seharusnya menjadi perhatian bagi guru, bukan hanya sebagai pengajar, tetapi juga sebagai pen- didik dengan prinsip sebagai berikut. Keterpaduan, yaitu baik dalam arti pelaksanaan pembelajaran antara isi tentang pengetahuan, sikap, spiritual perasaan, intelekrasional, fisik-jasmaniyah. Di samping itu, keterpaduan semua komponen untuk mendukung proses pembelajaran karakter dalam semua mata pelajaran/bidang studi. Semua guru, tata usaha, kepala sekolah, bahkan juga orang tua siswa bersama-sama melakukan pembentukan karakter siswa sesuai dengan fungsi, kewenangan dan kewajiban mereka masing-masing. Kesinambungan dan holistik, prinsip ini mengajarkan kepada kita bahwa pendidikan karakter tidak dapat dilakukan hanya sekali- sekali, insidental atau hanya pada momen- momen tertentu, tetapi juga harus dilakukan terus menerus. Pendidikan hidup bersih tidak dapat dilakukan hanya dengan mengajak anak bersih-bersih setiap hari Jumat atau Senin saja, tetapi juga harus dilakukan setiap hari dalam bentuk dan jenis kegiatan yang berbeda. Sinkronisasi, yaitu adanya kesejalanan antara yang diajarkan dengan yang dipraktikkan di sekolah, di rumah, dan di masyarakat.

Membentuk karakter bukanlah pekerjaan instan dan oleh satu institusi saja. Karakter seseorang terbentuk sebagai dampak akumulatif dari pelajaran yang dipetik dari perjalanan belajar dan bekerja sepanjang hidup seseorang yang melibatkan berbagai institusi, baik pendidikan formal, informal, maupun nonformal tempat seseorang menemukan dirinya sejak balita sampai dewasa melalui pendidikan yang tepat (Joni, 2008).

\section{Pembahasan \\ Strategi Kepemimpinan Kepala Sekolah}

Penelitian ini menemukan strategi pembentukan karakter dari perspektif kepala sekolah dilakukan melalui komunikasi 
falsafah, visi, misi secara jelas, keteladanan, disiplin, kepemimpinan instruksional, kepemimpinan mutu, dan pemberdayaan guru dan tenaga kependidikan. Temuan penelitian ini khususnya strategi fokus pada viisi dan misi ternyata bertentangan dengan penelitian Surachmi (2011:445) yang menyatakan indikator penetapan visi dan misi belum memberikan dukungan sepenuhnya ter hadap dimensi internal kepemimpinan kepala sekolah. Pertentangan ini terjadi antara lain karena perbedaan karakteristik subjek dan objek yang diteliti serta pendekatan penelitian yang digunakan. Penelitian ini meneliti di SDN Antara Kecamatan Trienggadeng Kabupaten Pidie Jaya. Penelitian ini menggunakan pendekatankualitatif,penelitian Surachmi me nggunakan pendekatan kuantitatif.

Temuan tersebut mendukung seperti yang dikemukakan oleh Willian dan Schnaps (1999) bahwa pendidikan karakter merupakan pendekatan yang dilakukan oleh semua staf, bahkan bersama-sama dengan orang tua murid dan anggota masyarakat untuk membantu agar anak menjadi peduli, berpendirian dan bertang- gung jawab. Pendidikan karakter hanya akan menjadi wacana jika tidak dipahami secara utuh, menyeluruh, menyatu dan melibatkan semua sumber daya yang terkait (integratedholistik). Hal ini sangat beralasan karena sifat pendidikan karakter adalah multi dimensi dan multi disiplin, sehingga diperlukan pendekatan yang komprehensif, utuh, interkonektif antar berbagai disiplin ilmu, sehingga pendidikan ka- rakter tidak hanya dibebankan pada satu bidang ilmu tertentu lebih-lebih di sekolah dasar, diperlukan integrasi pendidikan karakter pada semua mata pelajaran secara terintegrasi.

Temuan penelitian ini mendukung temuan Mondy \& Noe (1993) yang menyatakan bahwa budaya kerja sebagai sistem nilai, keyakinan dan kebiasaan bersama dalam suatu organisasi yang berinteraksi dengan struktur formal dapat menghasilkan norma perilaku. Penelitian ini juga mendukung penelitian. Hasri (2004) menyatakan bahwa nilai dan norma yang disosialisasikan sejak awal kepada anggota or- ganisasi dan mahasiswa akan manjadi peng- gerak kepada organisasi. Pengetahuan dan pe- maknaan nilai tersebut menjadi strategi bagi organisasi untuk mencapai kekuatan dan ke- unggulan dalam mencapai misi institusi.

Berbagai penelitian tersebut menggambarkan bahwa untuk membentuk budaya kerja berkualitas (termasuk budaya berkarakter) hendaklah dimulai dengan memberi pemahaman yang jelas tentang nilai dan budaya yang diinginkan kepada semua staf agar budaya dan nilai dapat dikembangkan. Hal tersebut juga ditegaskanoleh Jansen (2002) bahwa proses ter- bentuknya budaya dimulai dari pemahaman yang jelas terhadap doktrin (nilai dan kebiasaan/paradigma), penerimaan terhadap doktrin, dan dukungan elit organisasi dalam bentuk ke- teladanan yang kuat. Doktrin nilai, norma dan budaya kerja berkualitas harus diterima secara ikhlas dan dipahami secara jelas dan mendalam oleh semua anggota organisasi apabila organi- sasi mengingkan adanya kepatuhan dan imple- mentasi yang optimal oleh para staf. Tetapi, hanya sekadar pemahaman dan penjelasan dari pimpinan organisasi ternyata tidak cukup kuat untuk membentuk komitmen mereka terhadap nilai, norma dan budaya kerja berkualitas tanpa adanya keteladanan dari semua pimpinan dalam organisasi.

Keteladanan memberikan kontribusi yang sangat besar dalam mem bentuk sikap dan komitmen anggota organisasi, tanpa keteladan dari pimpinan kita tidak dapat berharap sesuatu yang lebih dari anggota orga- nisasi, apalagi berkaitan dengan sistem nilai dan budaya kerja berkualitas. Oleh sebab itu, tun- jukkan implementasi budaya kerja berkualitas dari pimpinan, maka secara perlahan akan kita temukan juga budaya kerja yang berkualitas dari staf kita.

Terkait dengan kepemimpinan, Hoover seperti dikutip oleh Sujarwo (2012) menyatakan bahwa keberhasilan 
pembentukan karakter akan ditentukan bukan hanya pada kekuatan pembelajaran, tetapi juga oleh kekuatan manajemen di unit organisasi sekolah yang berangkutan. Kekuatan manajemen sangat tergantung pada kualitas dan kekuatan kepala sekolah sebagai pemimpin.

Berbagai temuan penelitian ini dinyatakan juga oleh para ahli bahwa kepala sekolah memegang peranan yang sangat penting dan strategis dalam pembinaan dan pengembangan profesionalisme guru. Hal ini secara tegas dinyatakan oleh Glickman (1987), Bafaddal (2007) yang menyatakan bahwa tidak ada sekolah yang baik (termasuk guru yang baik) tanpa kepala sekolah yang baik. Kualitas sekolah sangat di- tentukan oleh kepala sekolah. Hal mendukung juga dinyatakan oleh Guthrie \& Schuerman (2011) bahwa kepemimpinan kepala sekolah menentukan performansi sekolah yang tinggi dalam budaya kerja berkualitas. Oleh sebab itu, Permendiknas Nomor 12 Tahun 2007 tentang Standar Pengawas/Madrasah dan Permendiknas Nomor 13 Tahun 2007 tentang Standar Kepala Sekolah/Madrasah antara lain menyatakan bahwa kompetensi kepala sekolah dan pengawas sekolah harus memiliki kompetensi untuk melakukan pembinaan kepada guru-guru dalam melaksanakan penelitian tindakan kelas dan karya ilmiah lainnya. Kepala sekolah adalah pembina, pembimbing, fasilitator, motivator dan mitra kerja bagi guru-guru dalam meningkatkan kompetensi dan profesionalismenya.

$$
\text { Dalam berbagai penelitian }
$$

kepemimpinan sekolah, kepala sekolah memiliki fungsi Educa- tor, Manager, Administrator, Supervisor, Lead- er, Entrepreneur, and Climator (EMASLEC) dalam rangka menjalankan sekolah menuju sekolah yang unggul. Dalam konteks pembinaan guru dalam keterampilan penelitian inilah maka kepala sekolah harus memiliki kemampuan dan keterampilan penelitian tindakan sekolah (school action research).
Hasil penelitian ini mendukung penelitian Usman (2013) yang menyimpulka $\mathrm{n}$ bahwa konsep strategi kepemimpinan instruksional antara lain adalah keteladan kepala sekolah dan guru. Keteladanan menurut Usman (2013) adalah ucapan (lisan dan/atau tertulis), bahasa tubuh, sikap, dan tindakan positif yang dapat di contoh oleh orang lain termasuk siswa. Kepala sekolah adalah "imam" di SDN Antara Kecamatan Trienggadeng Kabupaten Pidie Jaya. Selama "imam"nya bertindak benar, selama itu pula siswa sebagai "makmum" wajib menirukan gerak gerik "imam"nya. sebaiklnya, sebagai "imam" yang baik, ia wajib menerima teguran "makmum"nya ketika salah ucap atau salah tindakannya.

\section{Strategi Guru}

Penelitian ini menemukan bahwa strategi pembentukan karakter siswa dari perspektif strategi guru dilakukan melalui contoh teladan secara langsung setiap hari, pembiasaan melalui keterlibatan langsug melakukannya dalam pembelajaran dan sentuhan kalbu dengan kata-kata hikmah. Temuan penelitian ini mendukung pendapat Setyaningrum \& Husamah (2011) yang menyatakan bahwa pembelajaran semestinya memberi kesempatan kepada siswa untuk mengalami sifat-sifat (karakter yang diinginkan) tersebut secara langsung. Pendidikan karakter barupaya membantu siswa agar secaraa moral lebih bertanggung jawab dan menjadi warga negara yang lebih berdisiplin.

Hasil temuan penelitian ini selaras dengan yang dikemukakan oleh Arsyad (2010) bahwa strategi implementasi pembentukan sikap dan karakter dilakukan dengan cara pembiasaan, keteladanan, sentuhan kalbu (rasa dan kesadaran), kisahkisah dan kedisiplinan. Sementara itu, Sulhan (2010) menyatakan bahwa langkah pembentukan karakter adalah: (1) me masukkan konsep karakter dalam proses pembelajaran dengan cara menambah nilai kebaikan, menggunakan cara yang membuat anak memiliki alasan untuk berbuat baik, dan mengembangkan sikap mencintai 
berbuat baik; (2) membuat slogan yang mampu menumbuhkan kebiasaan baik; (3) pemantauan secara terus- menerus tentang kedisiplinan masuk, kebiasaan makan atau minum di kantin sekolah, kebiasaan berbicara, kebiasaan ketika di masjid/musholla serta memberi kesempatan dan atau melibatkan orang tua dalam menilai karakter anak.

Hal yang mendukung juga dikemukakan oleh Koesoema (2010) bahwa apabila ingin pendidikan karakter di sekolah berhasil secara efektif maka dalam programnya harus didasarkan pada tiga basis yaitu berbasis kelas, berba- sis kultur dan berbasis komunitas. Ini berarti bahwa peran guru dalam menciptakan karakter yang efektif sangat besar dalam desain pendi- dikan karakter berbasis kelas karena di sini terjadi interaksi dan relasi guru dan siswa secara intensip. Dengan demikian, semua nilai, norma dan kebiasaan yang baik dapat diterapkan dengan melibatkan siswa secara langsung di ba- wah bimbingan dan pengawasan guru. Hal ini apabila diperkuat dengan desain berbasis kultur maka akan menjadi cara yang dapat memperkuat apa yang dilakukan oleh siswa dalam kelas karena dalam berbasis kultur ini siswa diajak menciptakan taat aturan yang dibuat bersama seperti tentang kejujuran. Hal ini akan terlaksana apabila mereka tahu kenapa berbuat jujur kemudian melihat contoh langsung kemudian melakukannya dan diperkuat dengan aturan/tata nilai yang memiliki konsekuensi apabila me- langgar aturan.

Hasil penelitian ini juga mendukung pendapat Sujarwo (2012) bahwa strategi alternatif dalam pendidikan karakter (asrama sekolah) ditempuh dengan langkah-langkah seperti berikut. Pertama, pendekatan normatif dengan membuat tata kelola atau tata tertib yang di dalamnya dilandasi nilai-nilai, akhlak maupun budi pekerti. Kedua, pendekatan model, khususnya pimpinan sekolah (dalam pengertian ini sebenarnya termasuk guru sebagai pimpinan di kelas) dapat menjadi model atau contoh tela dan dalam ucapan, sikap dan perilakukannya sesuai dengan tata tertib yang telah dibuat bersama. Ketiga, pendekatan reward dan punishmen. Keempat, pendekatan suasana belajar, yaitu men- ciptakan suasana belajar agar dapat menjadi sumber inspirasi penyadaran nilai bagi semua orang dalam hal ini lingkungan belajar dapat dibuat dengan berbagai media yang berisi tentang katakata hikmah, Alqur'an atau hadist yang dapat mendorong kesadaran akan nilai- nilai kebaikan, kerja keras, jujur, disiplin dan lain-lain.

Temuan penelitian ini dalam persepektif guru menemukan strategi pelibatan aktif siswa (membiasakan), menjadi contoh teladan menyiapkan lingkungan belajar dengan kata-kata hikmah sejalan dengan pernyataan Djalil dan Megawangi (2006) dan Setyaningrum dan Husamah (2011) menyatakan bahwa ada beberapa hal yang harus dilakukan guru dalam imple- mentasi pendidikan karakter yaitu guru harus melibatkan siswa secara aktif, menciptakan lingkungan yang kondusif, dilakukan secara eksplisit, sistematis, dan berkesinambunga

Hal ini juga dipertegas oleh Suyatno (2010) yang menyatakan bahwa peran guru da- lam pembentukan karakter siswa dapat dilaku- kan dengan cara: terlibat aktif dalam pembelajaran bersama-sama siswa (interaksi dan disku- si), menjadi teladan bagi siswa dalam perilaku dan berbicara, mendorong siswa aktif dalam pembelajaran dan membuat perubahan serta mengembangkan emosi dan kepekaan sosial siswa menjadi lebih bertaqwa, menghargai ciptaan dan mengembangkan keindahan. Di samping itu, guru juga harus mengembangkan rasa cinta pada siswa-siswanya.

\section{Strategi Orang Tua dan Masyarakat}

Penelitian ini menemukan strategi pem- bentukan karakter dari perspektif strategi orang tua dan masyarakat adalah melalui komunikasi efektif, melibatkan orang tua dan masyarakat dalam merumuskan kebijakan pembentukkan karakter siswa serta melakukan pengawasan 
bersama terhadap perilaku siswa di sekolah dan di lingkungan rumah. Hasil penelitian tersebut mendukung pernyataan Lendrum (2003) yang menyatakan bahwa kerjasama kemitraan efektif sangat mendukung keberhasilan sekolah, tetapi hendaklah didasarkan kepada saling percaya antara institusi dengan pelanggan luar. Pene- litian ini juga mendukung pendapat Bell (1997) yang menyatakan bahwa kemitraan efektif yang kuat sekolah dengan orang tua dan masyarakat berlandaskan kepercayaan, tujuan bersama, kejujuran dan keseimbangan adalah faktor yang membawa keberhasilan organisasi dalam mem- betuk karakter siswa. Penelitian ini mendukung pendapat Branford (2000) yang menyatakan bahwa kemitraan efektif yang efektif adalah kerjasama yang saling menguntungkan antara pihak, dengan menempatkan kedua belah pihak dalam kedudukan setara dan mengandung pengertian usaha memenuhi keinginan institusi masing-masing. Dari berbagai pendapatpendapat di atas, jelaslah bahwa kemitraan efektif adalah sesuatu yang mutlak dilakukan oleh sekolah dalam membetuk karakter siswa karena dengan ke mitraan efektif tersebut sekolah dapat saling mengisi kelemahannya masing-masing melalui program kemitraan efektif sekolah dengan orang tua dan masyarakat. Di samping itu, kemitraan efektif juga dapat dijadikan sebagai patok duga (benchmarking) sekolah dengan orang tua dan masyarakat dalam mengembangkan program-program di sekolah untuk membentuk karakter siswa.

Berbagai hasil penelitian menunjukkan bahwa adanya kemitraan efektif yang baik antara sekolah dengan orang tua dan masyarakat dapat mewujudkan kepercayaan orang tua dan masyarakat terhadap pelayanan pendidikan di sekolah yang bermitra. Kepercayaan tersebut adalah sebagai dampak dari adanya kenyataan yang dapat dilihat oleh pelanggan dalam kua- litas proses layanan pendidikan dan kualitas produk institusi tersebut.
Sejumlah penelitian lainnya juga menemukan pengaruh keterlibatan keluarga/orang tua murid mulai dari jenjang pendidikan anak usia dini hingga sekolah menengah atas. Hendarson \& Mapp (2002) telah mereviu ratusan kajian dan menyimpulkan bahwa tingginya kua- litas keterlibatan keluarga dalam program pendidikan dapat meningkatkan dan mendukung prestasi belajar siswa. Hasil penelitian ini men dukung pendapat Grant \& Ray (2010) yang menyatakan bahwa siswa yang keluarganya terlibat dalam pendidikannya, maka anak akan mendapatkan keuntungan, yaitu: (1) earn high-er grades and test scores, (2) are less likely to be retained in a grade; (3) are more apt to ha-ven an accurate diagnosis for educational pla-cement in classes; (4) attend school regularly; (5) like school and adapt well to it; (6) have better social skills; (7) have fewer negative be- havior report, and; (8) graduate ang go on to postsecondary education.

Penelitian ini juga mendukung pendapat Epstein, dkk. (2009) yang menyimpulkan dari berbagai hasil penelitian penelitian di berbagai negara dan praktikpraktik di lapangan secara jelas menunjukkan bahwa keterlibatan orang tua masyarakat dalam pendidikan dapat mem- berikan keuntungan yang besar bagi siswa, se- kolah, orang tua murid dan masyarakat. Temuan penelitian ini mendukung pendapat Nor dan Hussin (2013) yang menyatakan bahwa orang tua dan masyarakat mempunyai pengaruh besar terhadap prestasi sekolah. Lebih lanjut dinyatakan bahwa pencapaian prestasi belajar anak bukan saja bergantung pada prestasi sekolahnya tetapi juga banyak dipengaruhi oleh cara hidup siswa yang bersangkutan. Di samping itu, kegiatan kolaborasi dalam masyarakat juga memainkan peranan penting sebagai pengaruh social yang sangat berpengaruh terhadap pencapaian prestasi siswa di sekolah itu.

Sementara itu, Marope (1996) menyata- kan anak yang mendapat dukungan kuat dari keluarganya 
menunjukkan prestasi yang lebih baik dibandingkan dengan anak yang kurang mendapat dukungan keluarga.

Epstein, dkk. (2009) menyatakan kemitraan efektif sekolah dengan masyarakat adalah sebagai bentuk kemitraan efektif (partnership) sebagai hubungan antara sekolah dengan individu masyarakat, organisasi dan busines yang bertujuan secara langsung atau tidak langsung untuk meningkatkan dan mengembangkan sosial, emosional dan fisik anak/siswa.

\section{Metode}

Penelitian ini menggunakan pendekatan kualitatif dengan jenis studi kasus di SDN Antara Kecamatan Trienggadeng Kabupaten Pidie Jaya. Instrumen penelitian adalah peneliti sendiri. Teknik pengumpulan data yang digunakan adalah wawancara mendalam, observasi, dan dokumentasi. Responden sebagai key informan adalah Kepala SDN Antara Kecamatan Trienggadeng Kabupaten Pidie. Responden bertambah terus (snow ball) sampai data yang diperoleh jenuh (redudancy). Waktu penelitian selama dua bulan. Data dianalisis sejak proses penelitian di la- pangan dilakukan sampai berakhirnya pengumpulan data dengan menggunakan teknik analisis data yang dikemukakan oleh Creswell (2014).

\section{Hasil Dan Pembahasan}

\section{Strategi Kepemimpinan Kepala Sekolah}

Berdasarkan hasil wawancara mendalam dan observasi selama di sekolah, diperoleh temuan kepemimpinan $\mathrm{k}$ epala sekolah SDN Antara Kecamatan Tri enggadeng kabupatn Pidie Jaya

\section{Filosofis Kepemimpinan}

Kepala sekolah sekolah SDN Antara Kecamatan Trienggadeng kabupaten Pidie Jaya memiliki filosofis kepemimpinan yang bernuansa pada aspek religius, yaitu beliau menganggap bahwa bekerja dan mempersiapkan umat untuk menjadi generasi yang berakhlak mulia dan cerdas adalah suatu ibadah. Karena filosofis kerja adalah ibadah. Oleh karena itu, kerja kepala sekolah selalu dilakukan secara ikhlas tanpa ada pamrih. Hal ini juga nampaknya memberikan inspirasi bagi tenaga pendidik dan tenaga kependidikan di lingkung- an sekolah.

Dalam proses kepemimpinannya, kepala sekolah selalu mekomunikasikan dengan ba- hasa yang sederhana tentang filosofis dan visi pribadi beliau serta keterkaitannya dengan visi sekolah kepada guru-guru untuk menumbuh- kan rasa saling membutuhkan dan berkepentingan, serta kreatif dalam menggerakkan orang untuk mendukung visinya. Kepala sekolah se- lalu menekankan hubungan saling ketergantungan dan saling membutuhkan antara sekolah dengan guru dan staf administratif lainnya. Kepala sekolah selalu menjelaskan bahwa sebagai sekolah swasta hidup dan matinya bergantung pengakuan dan penghargaan masya- rakat kepada sekolah. Hal tersebut akan tumbuh apabila semua tenaga di sekolah mampu memberikan yang terbaik bagi sekolah.

Filsafat kerja lain yang harus dianut dan selama ini menjadi cara bekerja kepala sekolah yaitu: kejujuran dan keadilan.Kejujuran selalu ditanamkan dan contohkan pada setiap gaya, perilaku dan praktik memimpin di sekolah de- ngan mengatakan bahwa apa yang kita katakan, harus sesuai dengan apa yang kita lakukan, atau dengan kata lain lakukan apa yang anda katakan dan katakan apa yang anda lakukan. Kepala sekolah mengatakan bahwa kalau Anda mau disegani dan diikuti oleh orang lain, maka satu kata yang tidak boleh Anda langgar adalah jujur.

\section{Keteladanan}

Dalam hal sikap keteladanan, Kepala Sekolah SDN Antara Kecamatan Trienggadeng Kabupaten Pidie Jaya menunjukkan sikap yang dapat menjadi contoh bagi semua warga sekolah dalam kehidupan di lingkungan sekolah. Keteladanan tersebut dilakukan sebagai berikut. Kepala sekolah selalu datang ke 
sekolah lebih awal dari guru dan siswa.Dari observasi yang dilakukan kepala sekolah selalu datang pada jam 07.00, sementara sekolah mulai berjalan jam 07.30 pagi dan guru-guru rata- rata datang pada jam 07.15.Kepala sekolah selalu bersikap ramah dan menyapa setiap guru dan murid serta orang tua murid, bahkan juga kepada peneliti se- lama melakukan observasi dengan kata-kata "Assalamualikum". Katakata tersebut selalu terucap oleh kepala sekolah saat bertemu orang lain di lingkungan sekolah selama pe- nulis observasi. Kepala sekolah selalu menempatkan diri sebagai teman sekaligus sebagai pengayom bagi guru-guru dan tenaga kependidikan lainnya serta siswa dan orang tua murid. Kepala sekolah dalam kepemimpinannya tidak hanya menjadi seorang atasan yang melin- dungi stafnya, tetapi juga dirasakan oleh warga sekolah sebagai teman, kakak atau saudara yang setiap saat menjaga, melin- dungi dan membimbing mereka ke arah kemajuan.

\section{Kedisiplinan}

Kepemimpinan kepala sekolah dalam perilaku sehari-hari selalu menunjukkan tingkat kedisiplinan yang tinggi dan diupayakan untuk selalu ditularkan kepada semua warga sekolah. Perilaku tersebut tampak terlihat pada saat diobservasi ke sekolah, kepala sekolah selalu lebih dahulu datang ke sekolah sebelum guru-guru dan tenaga lainnya, bahkan beliau datang ke sekolah hampir bersamaan dengan petugas kebersihan yang membuka kunci pagar sekolah.

Pada saat sekolah mengadakan rapat sekolah yang menghadirkan semua guru-guru juga terlihat kepala sekolah sudah berada di ruang rapat tepat sebelum rapat dimulai, dan pada saat itu hanya terdapat sebagian guru berhadir di ruang rapat. Pada saat ditanyakan kepada kepala sekolah mengapa hal itu Beliau lakukan: "Kepala sekolah menyatakan bahwa untuk membudayakan disiplin yang baik, maka harus kita mulai dari diri kita sendiri, tidak akan ada dsisiplin dari orang yang kita pimpin apabila kita tidak mampu menampilkan kedisiplinan pada diri kita sendiri”. Ternyata berdasarkan hasil observasi disiplin kepala sekolah mampu membuat disiplin guru dan akhirnya mampu mendisiplinkan siswa.

\section{Kepemimpinan Instruksional}

Kepemimpinan instruksional Kepala SDN Antara Kecamatan Trienggadeng Kabupaten Pidie Jaya , mengarah pada upaya yang kreatif dan terus-menerus melakukan perbaikan terhadap proses pembe- lajaran di sekolah. Hal tersebut nampak dari perilaku yang ditunjukkan sebagai berikut. Kepada sekolah selalu memiliki gagasan/ ide-ide yang inovatif dan disosialisasikannya kepada semua guru. Pada saat diwawancarai Beliau secara tegas menyatakan bahwa pem- belajaran adalah orientasi utama yang men- jadi pemikiran dan harapan serta tantangan dalam memajukan sekolah.

Kepala sekolah selalu berupaya mengembangkan kurikulum lokal berdasarkan kebutuhan daerah dan mengembangkan layanan penunjang belajar melalui pemberian les belajar yang dapat membantu murid belajar. Perilaku pengembangan kurikulum terkait dengan kebutuhan lokal nampak dari upaya kepala sekolah memberikan pemahaman ke- pada semua guru tentang Peraturan Daerah Nomor 6 Tahun 2018 tentang Pendidikan Alqur'an berkarakter Islami di sekolah sehingga lahir kebijakan khatam dan hafal Alqur'an.

Kepemimpinan kepala sekolah dalam menyikapi berbagai perkembangan dan inovasi pembelajaran bersikap sangat aktif dan se- lalu berupaya untuk mendapatkan informasi peruabahan tersebut. Hal tersebut nampak dari cara Beliau yang selalu memerankan diri untuk jemput bola guna lebih awal men- dapatkan informasi berbagai pembaharuan dan perubahan yang terjadi dalam proses pembelajaran. Hal itu ditunjukkan antara lain dengan mengundang para pakar dari perguruan tinggi untuk mendapatkan infor- masi dan mensosialisasikannya kepada semua tenaga pendidik. 


\section{Kepemimpinan Mutu}

Perilaku kepemimpinan kepala sekolah pada SDN Antara Kecamatan Trienggadeng Kabupaten Pidie Jaya sekolah nampak dari perilaku seperti berikut. Dalam rangka menuwujudkan sekolah men- jadi sekolah bermutu, kepala sekolah ber- upaya merumuskan standar mutu, kebijakan mutu, panduan mutu, dan standar operasional prosedur (SOP) untuk semua kegiatan di sekolah. Beberapa standar mutu yang dikembangkan oleh sekolah berkaitan dengan karakter dan ciri khas keunggulan sekolah ini dibandingkan sekolah lain adalah (1) shalat dengan keadaran; (2) berbakti kepada orang tua, (3) perilaku sosial baik, (4) tartil baca al-qur'an; (5) hafal juz 30; (6) nilai 5 bidang studi tuntas; (7) mempunyai kemampuan membaca efektif; (8) memiliki kemampuan komunikasi yang baik; (9) disiplin; (10) memiliki budaya bersih; (11) senang membaca; (12) percaya diri Sebagai pemimpin kepala sekolah menjadi orang pertama yang mengaplikasikan semua standar dalam melaksanakan tugasnya. Dalam perilakunya, kepala sekolah menunjuk- kan komitmen yang kuat terhadap standar yang telah disepakati bersama guru-guru dan tertuang dalam standar mutu, standar akademik maupun SOP. Kepala sekolah memiliki komitmen dan selalu berupaya meningkatkan profesionalisme guru secara terus-menerus (countinues de-velopment) melalui berbagai cara, seperti mendatangkan pakar, tokoh, dan lain-lain ke sekolah

\section{Pemberdayaan Guru dan Tenaga Kependidikan

SDN Antara Kecamatan

Trienggadeng Kabupaten Pidie Jaya menjadi salah satu faktor kunci yang mendapat perhatian serius oleh kepala sekolah. Kepala sekolah da- lam kepemimpinannya berupaya maksimal untuk melibatkan semua staf dalam berbagai ke- giatan di sekolah. Beliau beranggapan keterlibatan semua warga sekolah adalah sebagai salah satu cara membawa semua warga sekolah untuk bertanggung jawab terhadap kegiatan sekolah dan pencapaian visi dan misi sekolah. Upaya memberdayakan semua staf tersebut terlihat dari perilaku kepala sekolah dalam setiap kegiatan di sekolah, seperti: dalam menyusun kebijakan sekolah, kepala sekolah selalu mem- bicarakan dengan guruguru dalam suatu forum pertemuan. Semua guru diminta pendapatnya tentang kebijakan yang akan diambil. Hal tersebut nampak pada saat menyusun standar mutu yanag dikenal dengan 12 standar oleh sekolah. Standar tersebut dirumuskan bersama oleh ke- pala sekolah dengan guru-guru, bahkan juga melibatkan pihak orang tua murid dan komite sekolah. Setiap orang di lingkungan sekolah semua mendapatkan peran sesuai dengan kompetensinya masing-masing. Bahkan, untuk piket harian, semua orang diberdayakan untuk mem- bangun komitmen bersama dan rasa tanggung jawab yang besar bagi semua orang dalam menjalankan program sekolah dan menjadikan sekolah yang berprestasi.

\section{Strategi Guru}

SDN Antara Kecamatan

Trienggadeng Kabupaten Pidie Jaya tergolong favorit, bahkan mendapatkan status akreditasi B (baik). Sekolah ini seluruh gurunya bergelar sarjana, bahkan 21 guru sedang menyelesaikan program Magister. Sistem seleksi guru sangat ketat karena tidak hanya mendasarkan pada kemampuan akademik, tetapi juga kemampuan dan keterampilan tambahan, seperti baca tulis Al Qur'an dan karak- ter. Berdasarkan hasil observasi dan wawancara yang didukung oleh dokumentasi diperoleh gambaran bagaimana strategi guru dalam meng- integrasikan pendidikan karakter pada setiap pembelajaran, bahkan di luar pembelajaran. Beberapa temuan strategi tersebut adalah sebagai berikut.

\section{Keteladan}

Guru dalam melaksanakan pembelajaran di kelas dan di luar kelas selalu menunjukkan sikap, perilaku, dan 
tindakan yang sesuai de- ngan norma yang berlaku di sekolah dan ma- syarakat secara konsisten. Dalam pembelajaran, guru menggunakan kata-kata yang sopan kepada siswa, di luar kelas guru mengucapkan salam saat bertemu dengan siswa dan orang lain, berpakaian sesuai aturan sekolah, dating ke kelas tepat waktu, bahkan lebih awal. Guru mengakhir pelajaran juga tepat waktu. Hal lain terlihat guru selalu menunjukkan keteladan dalam berbudaya bersih sehingga saat akan memulai pelajaran guru meminta masingsaing siswa melihat ke sekitar tempat duduk masing- masing untuk melihat sampah, kemudian mem buangnya di tempat yang disediakan di dalam kelas.

\section{Pembiasaan}

Guru saat pembelajaran berlangsung menunjukkan sikap selalu melibatkan siswa untuk melakukan sesuatu seperti meminta siswa mengambil sampah dan meletakkannya ke dalam bak sampah, mengucapkan salam saat bertemu guru, mencuci tangan setelah memegangsampah. Kebiasanaan lain seperti membaca Al Qur'an yang merupakan ciri keunggulan sekolah yang dilakukan dengan sistem tagihan hapalan dari surah pendek sampai surah pan- jang dan akhirnya hapal juz. Hal ini terbukti pada saat bertemu dengan siswa diminta membaca ayat tertentu dari surah tertentu ternyata dia mampu menghapal ayat tersebut dengan baik dan lancar. Saat pembelajaran guru melatih siswa bekerjasama dengan teman lainnya, melatih keberanian mengemukakan pendapat dan lain-lain. Tampaknya strategi pembiasaan ini digunakan secara terintegrasi dalam pem- bentukan karakter siswa oleh semua guru di semua tingkat kelas.

\section{Sentuhan Kalbu}

Sekolah ini adalah sekolah dasar swasta yang berbasis keagamaan sehingga banyak ce- rita yang digunakan guru sebagai cara menyentuh kalbu adalah cerita yang Islami. Cerita tersebut berisi tentang bagaimana orang jujur, di- siplin, berani menyatakan yang benar dan kebenaran, kejujuran, ketegasan, kehormatan, kedisiplinan, penghargaan atas ilmu pengetahuan,yang tentunya baik untuk menumbuhkan sikap fleksibilitas, keterbukaan, ketegasan, pandangan ke depan, percaya diri, toleransi dan kemandirian. Cerita dan perumpamaanperumpamaan hikmah dan ungkapan yang dapat menyentuh hati diintegrasikan pada setiap pembelajaran apapun mata pelajarannya. Sentuhan kalbu ini juga dilakukan oleh sekolah dengan menempelkan kata-kata hikmah di dalam kelas dan di luar kelas yang pada umumnya diambil dari Alqur'an maupun hadist yang isinya mendorong sikap jujur, disiplin, kerja keras, belajar atau menun- tut ilmu pengetahuan, membaca Alqur'an, menghormati orang tua/orang dewasa dan lain-lain hikmah yang mendorong menjadi karakter yang baik.

\section{Strategi Orang Tua dan Masyarakat}

Berbagai kiat dilakukan oleh seorang kepala sekolah dalam membangun mutu sekolah hingga menjadi sekolah yang berkarakter, sekaligus berprestasi. Hal tersebut menjadikan SDN Antara Kecamatan Trienggadeng Kabupaten Pidie Jaya menjadi pilihan orang tua dan masyarakat dalam mendidik anak-anak mereka. Selain itu, juga terbina kemitraan efektif dengan berbagai pihak secara harmonis, mendukung, dan saling menguntungkan.

Dari data wawancara dengan para orang tua murid ditemukan bahwa kepala sekolah setiap saat paling tidak dua kali mengadakan pertemuan, baik formal ataupun informal. Pada pertemuan tersebut, kepala sekolah mengkomu- nikasikan visinya, menumbuhkan rasa saling membutuhkan dan berkepentingan, dan kreatif dalam menggugah orang tua untuk mendukung visi dan misi sekolah yang unggul dan berka- rakter. Di samping itu, kepala sekolah menyam- paikan masalah yang dihadapi dan menghimpun dukungan 
masyarakat terhadap kebutuhan sekolah. Di samping hal tersebut, kepala sekolah juga membuat program bersama dengan orang tua dan masyarakat, serta keterlibatan kepala sekolah dalam berbagai kegiatan di masyarakat, baik sebagai anggota organisasi masyarakat maupun sebabagi nara sumber semakin memberikan peluang dan berkembangnya kemitraan efektif sekolah dengan berbagai institusi, baik institusi pendidikan maupun institusi nonpendidikan.

Dengan adanya pendekatan formal dan nonformal,kepala sekolah kepada orang tua dan masyarakat, berdasarkan hasil wawancara men- dalam dengan orang tua dan masyarakat dan dari hasil observasi, diperoleh hasil penelitian, yaitu strategi yang dilakukan orang tua dan masyarakat dalam membentuk karakter siswa adalah komunikasi efektif timbal balik dengan pihak sekolah dan kemitraan efektif yang saling menguntungkan, membutuhkan, dan kesetaraan antara orang tua dan masyarakat dengan sekolah.

\section{Penutup}

Berdasarkan hasil pembahasan di atas, dapat disimpulkan bahwa strategi kepemimpinan kepala sekolah dalam membentuk guru adalah keteladanan, kedisiplinan, kepemimpinan instruksional dan mutu, serta pemberdayaan seluruh warga sekolah. Strategi guru dalam membentuk karakter siswa adalah keteladanan, pem- biasaan, dan sentuhan kalbu. Strategi orang tua dan masyarakat dalam membentuk karakter siswa adalah komunikasi dan kemitraan efektif.

Dalam membentuk karakter siswa sebaiknya kepala sekolah menerapkan strategi keteladanan, kedisiplinan, kepemimpinan instruk- sional dan mutu, serta pemberdayaan seluruh warga sekolah. Guru sebaiknya menerapkan strategi keteladanan, pembiasaan, dan sentuhan kalbu. Orang tua dan masyarakat sebaiknya menerapkan strategi komunikasi dan kemitraan efektif.

\section{Ucapan Terima Kasih}

Ucapan terima kasih penulis sampaikan kepada Bapak Saiful Rasyid, M.Pd, Kepala Dinas Pendidikan Kabupaten Pidie Jaya yang terus memotivasi penulis dalam menyelesaikan karya tulis ini, Ibu Apriani, S.Pd Pengawas Pembina SDN Pangwa terus membimbing penulis dalam melahirkan karya tulis ilmiah ini. dan kepada Kepala SDN Antara beserta seluruh guru dan tenaga kependidikan. Semoga semua pihak yang membantu penulis dalam memublikasikan artikel ini mendapat ganjaran Allah SWT. Amin.

\section{Daftar Pustaka}

Abraham, C. S. 2004. Strategic Planning A Practical Guide for Competitive Success. Canada: Thomson South Western.

Arsyad, A. 2010. "Strategi Implementasi Pen- didikan Karakter Bangsa di Perguruan Tinggi”. Makalah Seminar Nasional Pen- didikan Karakter Bangsa. Bogor: Balit- bangdiknas.

Bafadal, Ibrahim. 2007. "Kompetensi Profesional Kepala Sekolah dalam Perspektif UU Sisdiknas dan Permendiknas Nomor: 13 Tahun 2005". Makalah Seminar Na- sional di Banjarmasin. Banjarmasin: Program Magister Manajemen Pendidikan Unm.

Bell, C.R. 1997. Customer as Partners. Trans- late. Jakarta: Professional Book.

Brandsford, J., \& Darling-Hammond (Eds.). 2005. Preparing Teachers for a Chang-ing Word: What Teachers Should Learn and be Able to Do. San Fransisco, CA: Jossey-Bass.

Creswell, J.W. 2014. Research Design Quali-tative, Quantitative, \& Mixed Methods Approach. London: Sage. 
Depdiknas. 2003. Undang-Undang tentangm Sistem Pendidikan Nasional Nomor 20mTahun 2003. Jakarta: Depdiknas

Djalil, S.A. \& Megawangi, R. 2006. "Pening- katan Mutu Pendidikan di Aceh Melalui Implementasi Model Pendidikan Holistik Berbasis Karakter". Makalah Orasi Il- miah dalam rangka Dies Natalis ke-45 Universitas Syiah Kuala, 2 September 2006.

Epstein, J.L., Sander, M.G., Sheldon, S.B., Sio- mon, B.S., Salinas, C.S., Jansorn, N.R., Voorhis, F.L., Martin, C.S., Thomas, B.G., Greenfeld, M.D., Hutchins, D.J.,\& Wiliams, K.J. 2009. School, Family, and Community Partnership.YourHandbook for Action. Third Edition. United Kingdom, Singapore, Calipornia, New Delhi: Corwin Press A SAGE Company

Glickman, C, D. 1987. Developmental Supervi- sion. Alternative Practice for Helping Teachers Improve Instruction. Alexan- dria, Virginia: ASCD

Jalal, F. 2011. "Kebijakan Nasional Pendidikan Karakter". Makalah disajikan dalam Te- mu Pakar PAUDNI, di Jakarta, Tanggal 30 mei 2011Partnerships And Alliances.m Australia

Jansen, J. 2002. Mergers in Higher Education: Lessons Learned in Transitional Con- texts. Pretoria: University of South Africa Press.

Gardner, H. 2006. Five Minds for the Future. Boston: Harvard Business School Press.

Grant, K.B., \& Ray, J.A. 2010. Home, School, and Community collaboration. Kulturly Responsive Family
Involvement. Califor- nia: Sage Publication, Inc.

Guthrie, J.W \& Schurman, H. 2011. Leading School to Success.Los Angelis, London, Washington DC, Singapore: Sage.

Henderson, A., \& Mapp, K. 2002. A New Wave of Evidence: The Impact of School, Fa- mily and Community Connections on Stu- dent Achievement. Austin, TX: National Center for Family and Community Con- nections With School.

Hasri, S. 2004. Manajemen Pendidikan: Pende- katan Nilai dan Budaya Organisasi. Ma- kasar: Yayasan Pendidikan Makasar BTN Minasa.

Joni, T, Raka. 2008. "Model Pendidikan Guru dan Pendidikan Dosen, Prajabatan". Makalah Kongres nasional Pendidikan Indonesia (KONASPI) di Bali, 17-19

November 2008.

Kemendiknas. 2011. Panduan Pelaksanaan Pendidikan Karakter. Jakarta: Badan Penelitian dan Pengembangan. Pusat Kurikulum dan Perbukuan.

Koesoema, A.D. 2007. Pendidikan Karakter: Strategi Mendidik Anak di Zaman Glo- bal. Jakarta: PT Gramedia Widiasarana Indonesia.

Lendrum, T. 2003. The Strategic Patnering Handbook, The Practitioners' Guide To The McGraw-Hill Companies

Lickona, T. 2008. Educating for Character. nHow Our School Teach Respect and Res-ponsibility. New York: Bantam Books.

Maraope, P.T.M. 1996. The Impact of Educa- tional Policy Reform on the Distribution of Educational Outcome 
in Developing Countries: the Case of Botswana. Uni- versity of Botswana, IJED Vol. 16 No- mor 2.

Mondy, R.W., \& Noe, R.M. 1993. Human Resource Management. Massachusetts: Allyn \& Bacon.

Sauri, S. 2011. "Strategi Implementasi Pendi- dikan Karakter Bangsa di Perguruan Tinggi”. Makalah seminar Nasional Pen- didikan Karakter Bangsa. Bogor: Panitia seminar, Balitbangdiknas.

Setyaningrum, Yanur \& Husamah. 2011. "Op- timalisasi Penerapan Pendidikan Karakter di Sekolah Menengah Berbasis Keteram- pilan Proses: Sebuah Perspektif Guru IPA Biologi”. Jurnal Penelitian dan $P e$ - mikiran Pendidikan (JP3), Volume 2, Nomor 1, September 2011.

Sujarwo. 2012. "Manajemen Asrama Sekolah Berbasis Pendidkan Karakter (Studi Mul- ti Kasus di MA Unggulan Amanatul Um- mah Surabaya, SMA Ar-Rohmah Dau Malang dan MA Nurul Jadid Paiton
Pro- bolinggo)". Disertasi. Tidak Dipublikasi- kan. Malang: Universitas Negeri Malang

Sulhan. 2010. Pendidikan Berbasis Karakter, Sinergi antara Sekolah dan Rumah da- lam Membentuk Karakter Anak. Sura- baya: Jaringpena.

Surachmi, Sri. 2011. "Efektivitas Dimensi In- ternal Kepala Sekolah dalam Kepemim- pinan Pembelajaran". Cakrawala Pendi- dikan, XXX (3), hlm. 433-448).

Suyatno. 2010. "Peran Pendidikan Sebagai Mo- dal Utama Membangun Karakter Bangsa”. Makalah Sarasehan Nasional Pe- ngembangan Pendidikan Budaya dan Karakter Bangsa. Jakarta: Kopertis Wi- layah 3 DKI Jakarta.

Usman, Husaini. 2013. "Strategi Kepemimpin- an Pembelajaran Menyongsong Imple- mentasi Kurikulum". Cakrawala Pendidikan. No.XXXI (1), hlm. 1-13. 